\title{
INTERTEXTUALIDADE E INTERDISCURSO EM QUATRO PUBLICIDADES DE O BOTICÁRIO
}

\section{INTERTEXTUALITY AND INTERDISCOURSE IN FOUR O BOTICARIO ADVERTISINGS}

\begin{abstract}
Juliana de Fátima Ananias de Jesus
Wesley Luis Carvalhaes ${ }^{\mathrm{ii}}$

RESUMO: Esta pesquisa, à luz das contribuições teóricas dos estudos do texto e do discurso, propõe uma abordagem das relações intertextuais e interdiscursivas presentes em peças publicitárias impressas da empresa de cosméticos $\mathrm{O}$ Boticário. $\mathrm{O}$ estudo utiliza a metodologia documental de caráter qualitativa e toma como corpus de análise quatro publicidades de O Boticário, publicadas em 2005, criadas em estreita relação com contos de fadas conhecidos: Branca de Neve, Cinderela, Chapeuzinho Vermelho e Rapunzel. O estudo ressalta a ampla importância das reflexões de Bakhtin e Volochínov (2006) na compreensão das relações dialógicas presentes em todo texto. Como principal conclusão, a pesquisa confirma o postulado teórico de que todo processo de significação é social. Desse modo, o signo (tanto a palavra quanto a imagem) está sempre em processo de (re)significação, como se pode perceber no mapeamento das relações intertextuais e interdiscursivas nas publicidades analisadas.
\end{abstract}

PALAVRAS-CHAVE: Análise de discurso. Interação verbal. Intertextualidade. Interdiscurso. Publicidade.

ABSTRACT: This research, in light of theoretical contributions of text and discourse studies, proposes an approach to the intertextual and interdiscursive relations present in printed advertising pieces of $O$ Boticário cosmetics company. The study uses the documental qualitative methodology and takes as corpus of analysis four advertisings of O Boticário from 2005, elaborated in close relation with known fairy tales: Snow White, Cinderella, Little Red Riding Hood and Rapunzel. The study highlights the importance of Bakhtin and Volochínov's (2006) reflections on the comprehension of the dialogical relations present in every text. As main conclusion, the research confirms the theoretical postulate that every process of signification is social. Thus, the sign (both the word and the image) is always in the process of (re)signification, as seen in the intertextual and interdiscursive relations mapped in the advertisings.

KEYWORDS: Discourse analysis. Verbal interaction. Intertextuality. Interdiscourse. Publicity.

Submetido em: 31 out. 2018

Aprovado em: 30 nov. 2018

\footnotetext{
i Especialista em Língua Portuguesa: Texto, Discurso e Ensino pela Universidade Estadual de Goiás. E-mail: julianaananiasdejesus@hotmail.com.

ii Doutor em Letras e Linguística. Professor na Universidade Estadual de Goiás (UEG-Inhumas). Rede Goiana de Pesquisa sobre Texto, Discurso e Ensino. E-mail: wcarvalhaes@hotmail.com. 


\section{Introdução}

Este artigo objetiva discutir e compreender o funcionamento discursivo de quatro peças publicitárias da marca de cosméticos "O Boticário", da campanha "Conto de Fadas", lançada pela empresa no ano de 2005, desenvolvida em estreita relação com contos de fadas populares. Neste estudo, escolhemos as publicidades que se constroem com base nas histórias Branca de Neve, Cinderela, Chapeuzinho Vermelho e Rapunzel. Nessas publicidades, estabelece-se uma relação com os clássicos contos de fadas, com a finalidade de atrair o público-alvo da marca.

O artigo também objetiva analisar, com base no aparato teórico dos estudos do texto e do discurso, como se dão as relações de intertextualidade e de interdiscurso nas publicidades selecionadas. Para isso, consideramos as peças publicitárias em questão como textos verbo-visuais, cuja estruturação dáse por meio da materialidade linguística e de outras materialidades significativas, como a imagem. Para a abordagem dos textos selecionados, partimos da premissa de que é possível mapear e compreender as relações dialógicas presentes em qualquer texto, independentemente da materialidade significativa que o constitui.

Em nossa análise, percebemos que o aparato midiático, na campanha em questão, aproveita uma memória discursiva partilhada por boa parte do público consumidor dos cosméticos produzidos por "O Boticário", persuadindo-o, portanto, a comprar seus produtos.

Para o desenvolvimento do estudo, utilizamos a metodologia do levantamento bibliográfio, contemplando o levantamento teórico para a compreensão dos recursos utilizados pela linguagem publicitária das peças analisadas com base nos procedimentos metodológicos da pesquisa documental de abordagem qualitativa. Para a análise dos aspectos linguísticos e visuais nas quatro publicidades escolhidas, amparamo-nos nas contribuições teóricas dos estudos do discurso e do texto, com destaque para noções elaboradas por Bakhtin e Volochínov (2006).

Entendemos que nosso trabalho é relevante, pois possibilita identificar as relações de intertextualidade e de interdiscurso entre as publicidades 
selecionadas de "O Boticário" e os contos de fadas. Além disso, demonstra como a figura feminina é colocada nas publicidades escolhidas em comparação ao lugar que ocupa nos contos infantis.

\section{Princípios teóricos}

Ao tomarmos contato com as campanhas publicitárias que analisamos, relembramos coisas já vividas em algum momento de nossas vidas, principalmente fatos da nossa infância. Quando crianças, escutamos diversas vezes os contos sobre os quais se constroem as peças publicitárias analisadas. Esses contos nos chegam por meio de nossos avós, mães, pais, tios e tias, madrinhas e padrinhos ou até por amigos; depois, na nossa vida adulta, chega nossa vez de contar os mesmos contos para filhos, sobrinhos, afilhados e netos. Esses clássicos que sobrevivem a tantas gerações são carregados de memórias discursivas, de intertextos e interdiscursos trazidos de outro contexto histórico e acabam se adaptando a outros contextos sociais, em que os valores ideológicos são outros.

Sobre a possibilidade de um discurso estar interligado a outro já dito/escrito, é válido destacarmos o seguinte: "ao falar e/ou enunciar seu discurso, o sujeito enunciador está sempre se remetendo ao já dito, a outros discursos" (ORLANDI, 1983 apud SHOLTZ; KRUK, 2012, p. 03). Entende-se, portanto, que a atividade enunciativa é uma atividade dialógica, no sentido de que cada discurso faz parte de uma cadeia discursiva de base social, da qual cada enunciação é parte integrante.

Nessa perspectiva, faz-se necessário destacarmos que as relações dialógicas são constituintes fundamentais de qualquer atividade de linguagem, uma vez que "a relação dialógica é uma relação (de sentido) que se estabelece entre enunciados na comunicação verbal. Dois enunciados quaisquer, se justapostos no plano do sentido [...], entabularão uma relação dialógica". (FIORIN, 2012, p. 169). Assim, podem-se compreender as relações pertencentes ao universo social da língua, percebendo que as unidades textuais não são constituídas basicamente pelo seu próprio objeto estético, e sim no 
decorrer das relações sociais em que os discursos e textos se entrecruzam para formarem novos textos/discursos/enunciados.

Ainda sobre essas relações, ressaltamos as colocações de Bakhtin (1998) quando explica que nenhum texto começa do zero. Isso significa que a orientação dialógica é um acontecimento natural e oportuno de todo discurso, sendo que, em todos os percursos do texto/discurso, existe o encontro com discursos anteriores, vindo de outros lugares ou de textos já existentes. Para Bakhtin (1998, p. 88), "apenas o Adão mítico que chegou com a primeira palavra num mundo virgem, ainda não desacreditado, somente este Adão podia realmente evitar por completo esta mútua orientação dialógica do discurso alheio para o objeto". Isso porque, mitologicamente, Adão foi o primeiro a produzir o discurso humano, concreto e histórico, não sendo possível ser de outra forma. Nós, que nos comunicamos por meio da linguagem - pela língua e por outros múltiplos conjuntos significativos, bem ao contrário do mítico Adão, não somos a fonte do que enunciamos. Nossa atividade de linguagem integra a cadeia ininterrupta da interação verbal (BAKHTIN; VOLOCHÍNOV, 2006), de modo que aquilo que enunciamos funciona como uma resposta a outros enunciados e, na mesma medida, instaura a possibilidade de que outros enunciados surjam a partir do nosso.

Com base na visão dialógica da língua, apresentada em Bakhtin e Volochínov (2006), compreendemos que o texto se estabelece como a materialidade do sujeito, constituindo espaço de diálogo entre este e a exterioridade. Reconhecendo a presença de vozes que aparecem nos textos, Bakhtin e Volochínov (2006) afirmam que a interação verbal se apresenta como elemento importante na construção da língua. Desse modo, determinadas expressões em alguns enunciados surgem de outros já existentes e se manifestam como consequência da interação entre eles. Se tomarmos a língua apenas como forma, podemos isolá-la do indivíduo que a utiliza. Entretanto, tomando a língua como fenômeno da interação verbal, entendemos que ela é "produto de uma criação coletiva, um fenômeno social e, portanto, como toda instituição social, normativa para cada indivíduo" (BAKHTIN; VOLOCHÍNOV, 2006, p. 79). 
Nesse ponto de vista, os enunciados são constituídos com visões de mundo diferentes, portanto, não são neutros, pois apresentam em suas composições sentidos oriundos de outros textos/enunciados já conhecidos. Sendo assim, é preciso destacar, mais uma vez, as observações de Bakhtin e Volochínov (2006) ao afirmarem que a língua estabelece um caminho contínuo de atos de fala, em que coisa nenhuma continua imutável, nada permanece com sua personalidade. Toda enunciação, cada ação particular é excepcionalmente única e não reiterável, contudo, em toda enunciação, encontramos informações semelhantes às de distintas enunciações partilhadas por um grupo de falantes. Em outras palavras, a parte material que constitui um enunciado - uma palavra, uma frase, uma imagem - pode ser repetida reiteradas vezes. Mas o sentido, a "alma" do enunciado, que depende diretamente da situação de enunciação, é sempre nova e única.

Ainda na perspectiva de língua como interação verbal, destacamos que tal processo se constitui como uma realidade fundamental da língua e o diálogo, compreendido em seu vasto sentido, é uma de suas formas mais importantes,

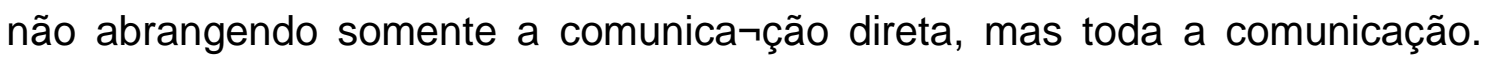
Conforme destacam Bakhtin e Volochínov (2006, p. 127, grifos dos autores),

A verdadeira substância da língua não é constituída por um sistema abstrato de formas linguísticas nem pela enunciação monológica isolada, nem pelo ato psicofisiológico de sua produção, mas pelo fenômeno social da interação verbal, realizada através da enunciação ou das enunciações.

Dessa concepção de língua, deriva a noção de leitura como uma atividade social por meio da qual o sentido é construído. Segundo Brait (2012), a leitura é um processo de produção do sentido. Essa concepção dá base à noção discursiva de leitura que põe em relevo as concepções dialógicas de base bakhtiniana, segundo as quais não existe texto pronto ou completo por si só. Ao contrário, os textos, e os discursos neles materializados, compõem uma relação dialógica constitutiva com outros textos e discursos que os antecedem e deles se originam. Brait (2012) explica bem como se estrutura a noção de texto nos trabalhos de Bakhtin. 
O conceito bakhtiniano de texto produzido pelos trabalhos de Bakhtin/Voloshinov afasta-se de uma concepção que o colocaria como autônomo, passível de ser compreendido somente por seus elementos linguísticos, por exemplo, ou pelas partes que o integram, para inserilo numa perspectiva mais ampla, ligada ao enunciado concreto que 0 abriga, a discursos que o constituem, a autoria individual ou coletiva, a destinatários próximos, reais ou imaginados, a esferas de produção, circulação e recepção, interação. (BRAIT, 2012, p. 10).

Na perspectiva bakhtiniana, portanto, o texto nunca é completo sozinho, pois sempre existe uma relação como algum outro texto/discurso já dito ou vivido anteriormente. Obviamente, conforme esclarece Brait (2012), há, nos textos, elementos de duas dimensões: elementos linguísticos e elementos extralinguísticos. Os elementos linguísticos do texto pertencem à ordem da língua e, como tal, podem ser repetidos, escritos ou falados muitas vezes, em diferentes situações. Os elementos extralinguísticos pertencem à ordem do discurso, da enunciação, e, portanto, não se repetem. O discurso é sempre original, embora seja materializado por meio de elementos já conhecidos. A novidade do discurso, reside, portanto, nas múltiplas possibilidades significativas de qualquer materialidade semiótica tomada como enunciado.

Todo enunciado carrega um valor social, que Bakhtin e Volochínov (2006) denominam valor ideológico do signo: "tudo que é ideológico possui um significado e remete a algo situado fora de si mesmo. Em outros termos, tudo que é ideológico é um signo. Sem signos não existe ideologia" (BAKHTIN; VOLOCHÍNOV, 2006, p. 29, grifos dos autores). De acordo com os teóricos, tudo o que é ideológico apresenta um significado e nos traz alguma coisa que está localizada fora da materialidade semiótica e que a constitui. Sendo assim, todo signo, para significar, é "revestido" de um valor ideológico. Qualquer elemento físico pode ser transformado em signo quando, sem deixar de ser componente da realidade material, passa também a existir em certa medida em uma outra realidade ideológica.

Sobre a importância dos enunciados como produto de interação social entre os sujeitos, é importante destacar o que dizem Bakhtin e Volochínov (2006), tendo em vista que, nas colocações dos autores, a palavra é sempre dirigida a alguém. Afinal, não falamos para nós mesmos, sempre que falamos dirigimos nosso discurso a alguma pessoa, não sendo possível haver interlocutor abstrato. Vejamos a seguir: 
A enunciação é o produto da interação de dois indivíduos socialmente organizados e, mesmo que não haja um interlocutor real, este pode ser substituído pelo representante médio do grupo social ao qual pertence o locutor. A palavra dirige-se a um interlocutor: ela é função da pessoa desse interlocutor: variará se se tratar de uma pessoa do mesmo grupo social ou não, se esta for inferior ou superior na hierarquia social, se estiver ligada ao locutor por laços sociais mais ou menos estreitos (pai, mãe, marido, etc.). Não pode haver interlocutor abstrato; não teríamos linguagem comum com tal interlocutor, nem no sentido próprio nem no figurado. (BAKHTIN; VOLOCHÍNOV, 2006, p. 114-115, grifos dos autores).

Levando em consideração as particularidades dialógicas do texto, podemos ressaltar que ele é marcado pelo intertexto que constrói dialogicamente com textos anteriores e posteriores, nunca surge do nada. Na realidade, apoia-se em algum respaldo dialógico e se fundamenta nos processos sociais e na interação dos sujeitos e dos textos. Acerca do dialogismo que constitui a linguagem e, por conseguinte, o texto, Knoll e Pires (2010, p.211) afirmam que Bakhtin

\begin{abstract}
defende que o dialogismo é propriedade fundamental da linguagem (seja como língua, seja como discurso), princípio que se estende à sua concepção de mundo e de sujeito. Há uma dialogização interna da linguagem, uma vez que a palavra de um é inevitavelmente atravessada pela palavra do outro. Considerando que, assim como um texto, o ser humano é tecido discursivo, portanto dialógico e fundado nos processos sociais (princípios de alteridade e intersubjetividade), 0 dialogismo reflete também a interação entre os sujeitos. O dialogismo pode, então, ser compreendido de duas maneiras; entre discursos (interdiscursividade e intertextualidade), e como diálogo entre sujeitos (constituídos no discurso).
\end{abstract}

Nesse sentido, percebemos que o dialogismo é um princípio constituinte da língua/linguagem, das falas, dos discursos e, principalmente, dos sujeitos que são constituídos no curso das interações sociais. Tendo estabelecido essa questão de que o discurso de um muitas vezes se mantém no discurso do outro, podemos imaginar até que ponto isso é visível ou ocultado em textos. Partindo desse pressuposto, vemos a necessidade de compreender um pouco mais a noção de intertextualidade e de interdiscurso e como esses termos se relacionam com o dialogismo.

De acordo com Fiorin (2012, p. 162, grifo do autor), "a palavra intertextualidade foi uma das primeiras, consideradas como bakhtinianas, a ganhar prestígio no Ocidente. Isso se deu graças à obra de Júlia Kristeva". Fiorin 
(2012, p. 164), retomando a concepção bakhtiniana de texto, afirma que "todo texto é um intertexto; outros textos estão presentes nele, em níveis variáveis, sob formas mais ou menos reconhecível. Assim, a intertextualidade é a maneira real de construção do texto".

Na perspectiva bakhtiniana, portanto, um texto é por princípio intertextual, embora nem sempre os elementos que estabelecem essa intertextualidade sejam facilmente localizáveis. Sobre a distinção entre a relação intertextual e a interdiscursiva, Fiorin (2012) define qualquer relação dialógica, na maneira em que é uma relação de sentido, como interdiscursiva. Isso significa que o termo intertextualidade permanece protegido exclusivamente para os acontecimentos em que a relação discursiva é consolidada em textos. Isso denota que a intertextualidade implica continuamente uma interdiscursividade, contudo o contrário não é correto. Por exemplo, quando a relação dialógica não aparece no nível do texto, temos interdiscursividade, porém não intertextualidade.

Ainda a respeito das diferenças encontradas entre interdiscursividade e intertextualidade, continuamos enfatizando as concepções de Fiorin (2012, p. 191) que salienta:

\footnotetext{
Pode-se fazer uma diferença entre interdiscursividade e intertextualidade. Aquela é qualquer relação dialógica entre enunciados; esta é um tipo particular de interdiscursividade, aquela em que se encontram num texto duas materialidades textuais distintas. Cabe entender que, por materialidade textual, pode-se entender um texto em sentido estrito ou um conjunto de fatos linguísticos, que configura um estilo, um jargão, uma variante linguística, etc. O caráter fundamentalmente dialógico de todo enunciado do discurso impossibilita dissociar do funcionamento discursivo a relação do discurso com seu outro.
}

Pensando na noção de interdiscursividade, notamos que ela está espontaneamente ligada à memória discursiva, o que corresponde aos discursos que se estabelecem a partir do encontro com outros discursos/textos. Nas palavras de Orlandi (2002, p. 22), "todo dizer se acompanhada de um dizer já dito e esquecido que o constitui em sua memória. A esse conjunto de enunciações já ditas e esquecidas e que são irrepresentáveis é que damos o nome de interdiscurso". 
Na mesma perspectiva, Fernandes (2005) destaca que toda concepção discursiva expõe interiormente o aspecto de distintos discursos, fenômeno que a Análise do Discurso designa como interdiscurso. Essa noção diz respeito a uma interdiscursividade marcada pelo entrelaçamento de distintos discursos originários de distintos períodos na história e de diferentes lugares sociais.

Esse entrelaçamento pode ser percebido nas quatro peças publicitárias que analisamos. Segundo Souza (2008), a publicidade faz parte do nosso cotidiano e tem como maior objetivo persuadir o consumidor a comprar aquilo que está sendo anunciado, mostrando sempre as vantagens de quem adquirir tais produtos, vejamos a seguir:

\begin{abstract}
A publicidade faz parte definitivamente da cultura contemporânea. Ela geralmente tem nos informado sobre o que deve ser considerado bom e mau, certo e errado, belo e feio, normal e anormal. Propostas de valores, estilos de vida, formas de relacionamento, entre outras coisas, são sugeridas, insinuadas e até mesmo impostas nas publicidades. $O$ discurso publicitário é tido como veladamente autoritário, imperativo em boa parte das vezes, habilmente disfarçado através de recursos das figuras de retórica, nas quais os produtos são elogiados pela sua beleza, facilidade, comodidade e outros aspectos. A linguagem é, nesse tipo de discurso, uma forma de poder e a Retórica uma "arte da persuasão", a qual permite convencer o ouvinte do discurso proposto. $\mathrm{Na}$ verdade, retoricamente, podemos dizer que a publicidade não somente convence e persuade pela sua característica de discurso argumentativo, como também seduz e contagia. Por meio de seu discurso, o orador (ou o sujeito comunicante/enunciador) se esforça para impor suas representações, suas formulações e para orientar uma ação. (SOUZA, 2008, p. 36).
\end{abstract}

Tendo em vista que o principal objetivo da publicidade é persuadir o interlocutor para uma possível venda do produto, as campanhas publicitárias circulam socialmente em todos os campos de atividade humana, permanecendo sempre em contato direto com as pessoas por diferentes meios de comunicação, principalmente os mais acessíveis como a TV, os jornais e as revistas e, atualmente, com grande força na internet, nas redes sociais. A esse respeito, Resina (2009, p. 160) afirma que "o texto publicitário tende quase sempre a ser objetivo [...] para cumprir seu papel persuasivo, por meio da estimulação dos sentidos e da emoção, que, por sua vez, regula a intensidade da manipulação sobre o destinatário-leitor". Talvez por tamanha acessibilidade, a sociedade conviva com tanta familiaridade com os conceitos transmitidos pelo texto publicitário. 


\section{Análise das quatro publicidades de 0 Boticário}

As análises feitas a seguir são possíveis a partir de textos verbo-visuais, tomados como enunciados que se articulam a outros já conhecidos antes em outro lugar e outra época, presentes em outros textos. A significação desses textos dá-se pelo interdiscurso e pelo intertexto, que objetivamos mapear em nossa abordagem.

Figura 1 - Publicidade d'O Boticário com referência a Branca de Neve

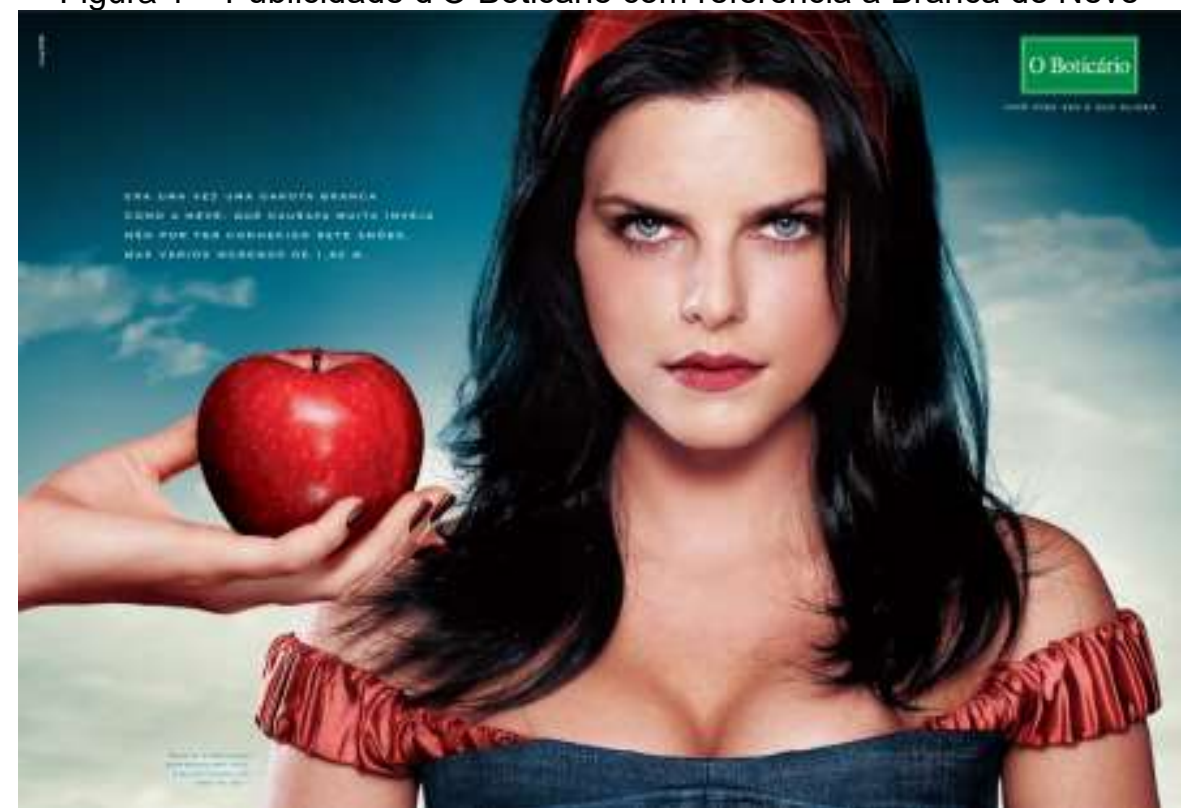

Fonte: http://mundofabuloso.blogspot.com/2008/01/o-boticario-e-suas-princesas.html. Acesso em: 05 fev. 2018.

Iniciamos nossa análise com a imagem da Branca de Neve. E o que é mais impactante nessa fotografia é o olhar intenso, fixo e provocante da "princesa", muito distinto do seu protótipo, que é continuamente lembrada como uma moça docemente fascinante e encantadora. Entretanto, nessa peça publicitária, a doçura, o encantamento e o fascínio deixam de existir e sobrevém a sedução.

Percebemos a importância, ao lado da imagem da princesa, do enunciado verbal que diz "Era uma vez uma garota branca como a neve, que causava muita inveja não por ter conhecido os sete anões, mas vários morenos de 1,80 m". Esse enunciado mostra que não há intenção de alcançar o público infantil, o que 
é frequente no conto de fadas, mas o público adulto. Afinal, nessa imagem, até temos a menina de cabelos negros, pele clara e boca vermelha como o sangue, mas esses elementos já não carregam mais a característica de fragilidade. Os olhos evidenciam e demonstram poder de confiança, seus seios são grandes e sensuais e a frase evidencia que os homens que a cobiçam são estereótipos do homem perfeito, isto é, morenos, altos e fortes. Uma vez que, na imagem, temos a Branca de Neve com um olhar tão marcante e sensual, chegamos a questionar se são realmente os homens que a cobiçam ou se ela agora, sendo tão determinada e ousada, sai à procura e os captura.

A publicidade "conversa" com o conto infantil com o qual estabelece relação, pois é desse conto que emerge a memória discursiva que nos faz (re)significar a peça publicitária. Entretanto, é interessante notar como as relações interdiscursivas apontam novas possibilidades de sentido. No conto, Branca de Neve é auxiliada pelo grupo simpático dos "sete anões", que lhe dão abrigo e proteção. Na publicidade em questão, não há mais a figura dos anões, mas a de "vários morenos de 1,80 m". Os anões são substituídos por homens altos e morenos que concretizam o ideal de beleza masculina que povoa 0 imaginário de muitas mulheres, público-alvo do anúncio. À candura da personagem que se mostra indefesa no conto, opõe-se a sensualidade da "nova" Branca de Neve, cujos olhos revelam os traços de personalidade de uma nova mulher, não mais indefesa, mas corajosa, destemida e "senhora de si".

Outro elemento característico da imagem não menos importante são as cores presentes em toda a figura. Em destaque, temos o uso da cor vermelha presente na maçã, nas alças do vestido, na fita do cabelo, nas unhas da mão de quem oferece a maçã e nos lábios da moça. Popularmente, essa cor tende a denotar o sentido de paixão, proibição, excitação e sedução, o que reforça a ideia de mulher decidida, forte, sedutora e independente, que figura no mundo contemporâneo.

Observando a imagem, temos ainda a sensação de que o anúncio deseja criar identificação com mulheres decididas, sedutoras, sensuais e independentes. Isso fica sugerido no semblante da "donzela", detentora de sobrancelhas delineadas, cabelos repicados, vestido jeans, maquiagem bem produzida e decote definido, possibilitando o destaque aos seios grandes e 
sexys. O volume dos seios pode até ser interpretado como uma possível prótese de silicone, o que reforça ainda mais a imagem da mulher contemporânea.

Percebemos a ocorrência de intertextualidade, tanto nos componentes linguísticos presentes na frase ao lado da Branca de Neve, quanto nos elementos visuais, destacando a característica da princesa em questão, pele clara com os cabelos pretos, a quem é oferecida uma maçã. Entretanto, o discurso que se materializa na publicidade é bem diferente daquele que se percebe no conto. É dessa relação interdiscursiva que emergem os possíveis sentidos dos quais estamos falando.

Ao fundo da imagem, temos uma contradição com as cores quentes, presentes nas nuvens em tons dégradé de azul, sugerindo suavidade e tranquilidade, bem como as letras em branco confirmando essa sugestão de algo natural. A posição da maçã na superfície principal pode representar a transição da fase ingênua para a sensual, uma vez que a maçã remete à memória discursiva do pecado em razão do discurso religioso estabelecido com base na bíblia cristã. Contudo, ao analisar o posicionamento atual de muitas mulheres, nota-se que já não se privam de envolvimentos amorosos sem nenhum compromisso e não enxergam nisso nenhuma malícia que necessite de repressão, demostrando mais ainda sua nova visão e opinião perante a sociedade. Até pouco tempo, a mulher era educada para ser a dona de casa exemplar - o que é reforçado pelo conto, no qual a princesa é "acordada" pelo beijo do príncipe com quem se casa - comprometida com o seu marido e o bemestar da família e não possuía sequer o poder de escolha, situação bem diferente da que é sugerida na imagem.

$\mathrm{Na}$ segunda publicidade selecionada, temos a personagem Cinderela, conhecida pelo sofrimento e os maus tratos de sua malvada madrasta, que por anos a proibiu de viver com liberdade sua vida. No entanto, na peça publicitária, a Cinderela não traz consigo esses traços de sofrimento, mas os de uma mulher moderna e decidida. Percebemos isso inicialmente no olhar firme e seguro de si, nas luzes do cabelo, no vermelho dos lábios, bem como no decote.

No entanto, o contraste da cor do vestido e as flores do cabelo dão uma aparência de sensibilidade, inocência, pureza e comprovam as descrições prototípicas de uma bela princesa. Alguns elementos nos remetem à 
intertextualidade com o conto, pois toda princesa precisa ser bonita, educada, delicada, tal qual vemos na imagem. O fundo azul sugere um ambiente de tranquilidade, que também se associa ao imaginário social sobre uma princesa.

Figura 2 - Publicidade d'O Boticário com referência a Cinderela

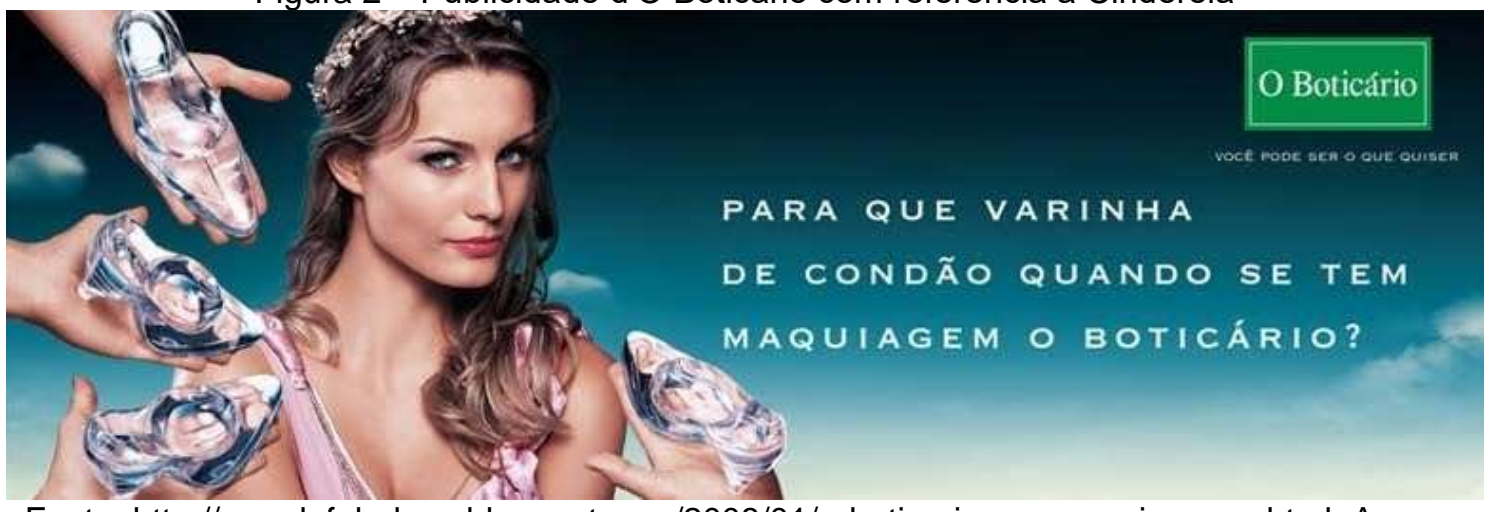

Fonte: http://mundofabuloso.blogspot.com/2008/01/o-boticario-e-suas-princesas.html. Acesso em: 05 fev. 2018.

Outro fator importante a ser analisado são os sapatos apresentados por diferentes mãos, supostamente masculinas, que dão uma ideia de sedução e de domínio. Afinal, não há somente um príncipe procurando por essa mulher, desejando-a e querendo que ela prove o sapato e seja a princesa dos sonhos. A presença dos sapatos é um elemento intertextual, mas o fato de haver vários sapatos, sugerindo que há vários príncipes à procura de Cinderela, inaugura possibilidades novas de significação. Isso evidencia também que ela detém o poder de escolha e um certo domínio sobre os homens que a desejam e querem conquistá-la, algo bem diferente do contexto do conto a que a publicidade faz referência.

Não podemos deixar de mencionar a frase "Para que varinha de condão quando se tem maquiagem O Boticário?", que coloca em destaque o ideal de usar e aproveitar os produtos de "O Boticário". Sendo assim, não será mais necessária nenhuma magia para que a mulher fique bela e atraente, uma vez que a magia se encontra nos produtos da marca em questão, que deixarão a mulher encantadora e perfeita, tal qual ela deseja. Ao contrário do conto de fadas, a Cinderela não necessita mais da magia da sua fada madrinha para que se transforme na bela princesa que fez o príncipe se apaixonar. Agora, ela dispõe 
de outra magia, os produtos "O Boticário". Essa magia também está presente na publicidade seguinte, que retoma o conto Chapeuzinho Vermelho.

Figura 3 - Publicidade d'O Boticário com referência a Chapeuzinho Vermelho

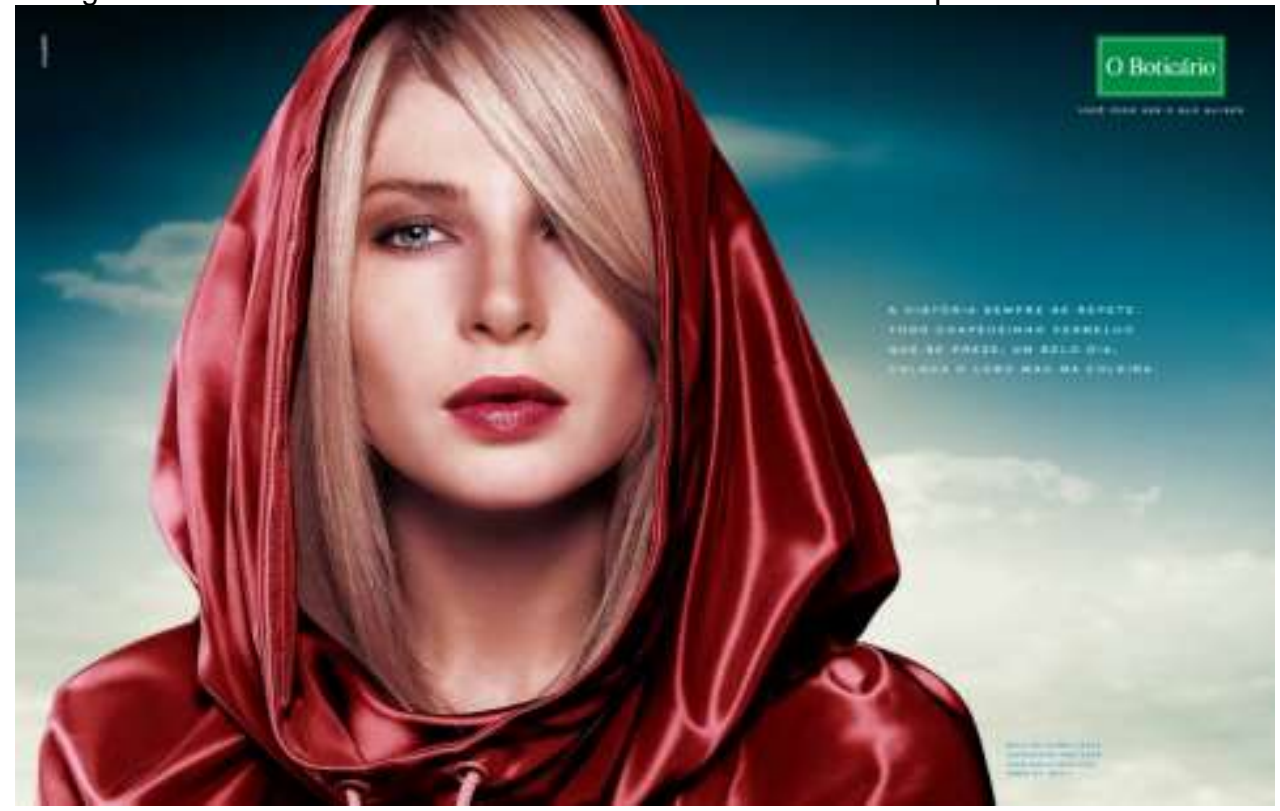

Fonte: http://mundofabuloso.blogspot.com/2008/01/o-boticario-e-suas-princesas.html. Acesso em: 05 fev. 2018.

Nessa terceira publicidade, temos a Chapeuzinho Vermelho. Como nas demais imagens, há traços bem diferentes da personagem original dos contos, afinal, na campanha publicitária, o tom de vermelho é bem distinto do que imaginamos que a menininha vestia ao levar os doces da vovó. A cor da capa é mais vibrante, com um perolado encantador; intuímos ainda que é feita de um tecido acetinado, recordando a fineza, a delicadeza e a sedução da mulher moderna. Seus lábios são bem carnudos, o que nos faz lembrar do estereótipo de beleza feminina da contemporaneidade; o batom vermelho reforça novamente o conceito de encanto e sedução; a pele muito limpa, lisa e bem tratada com aparência de maciez completa o ar de sedução.

O fundo azul celestial do anúncio faz perfeita combinação como os olhos também azuis da modelo que representa a Chapeuzinho. O anúncio faz referência, como nos anteriores, a um dos estereótipos de mulher contemporânea do século XXI, loira, alta, de olhos azuis, totalmente distinta da pequena Chapeuzinho dos contos de fadas. 
Outro fator que chama atenção é o texto verbal: "A história sempre se repete. Todo Chapeuzinho Vermelho que se preze, um belo dia, coloca o lobo mau na coleira". Percebemos, nesse trecho, uma inversão de valores, uma vez que atualmente não é mais o "Lobo Mau" que tem força e poder, mas a Chapeuzinho, que se tornou uma mulher forte, bem decidida e muito bonita. É dela o poder de mandar e decidir, afinal só quem manda "coloca o lobo mau na coleira”. O lobo, um perigo na história infantil, é domado e domesticado pela Chapeuzinho atual. As letras estão destacadas e com nuanças de branco, reforçando cada vez mais a seriedade dessa condição de submissão do lobo, que representa o homem, que está encantado e rendido pela Chapeuzinho.

Se pensarmos que o "Lobo Mau" sejam as rugas na pele causadas pela passagem de tempo e idade da mulher, o que atualmente também é um fator de grande preocupação não só do público feminino, podemos dizer que, nesse caso, temos outra vez uma relação de submissão. Entretanto, dessa vez, é a mulher - que muitas vezes se sente na obrigação de se adequar a esse padrão imposto -, possível compradora de produtos "O Boticário", que se submete a valores sociais que supervalorizam a beleza e a perfeição estética.

Não podemos deixar de mencionar elementos da ordem do repetível que se mantêm, como por exemplo as expressões "Lobo Mau," "Chapeuzinho", "era uma vez", "um belo dia", bem como a imagem da capa vermelha, os quais nos permitem estabelecer uma relação intertextual, embora os sentidos, como é próprio da atividade enunciativa, sejam completamente diferentes nesse contexto. Outro fator relevante a ser mencionado que acontece não somente nessa imagem em questão, mas também nas outras, é a questão de a figura feminina ser estereotipada. As três peças publicitárias analisadas até aqui, como também acontecerá na peça seguinte, apresentam a mulher em uma perspectiva diferente, especialmente em sua caracterização física, especialmente naquilo que refere à maquiagem e ao arranjo dos cabelos. Sabemos que esse não é obrigatoriamente o modo de ser de todas as mulheres, mas é visto como padrão a ser seguido por muitas. 
Figura 4 - Publicidade d'O Boticário com referência a Rapunzel

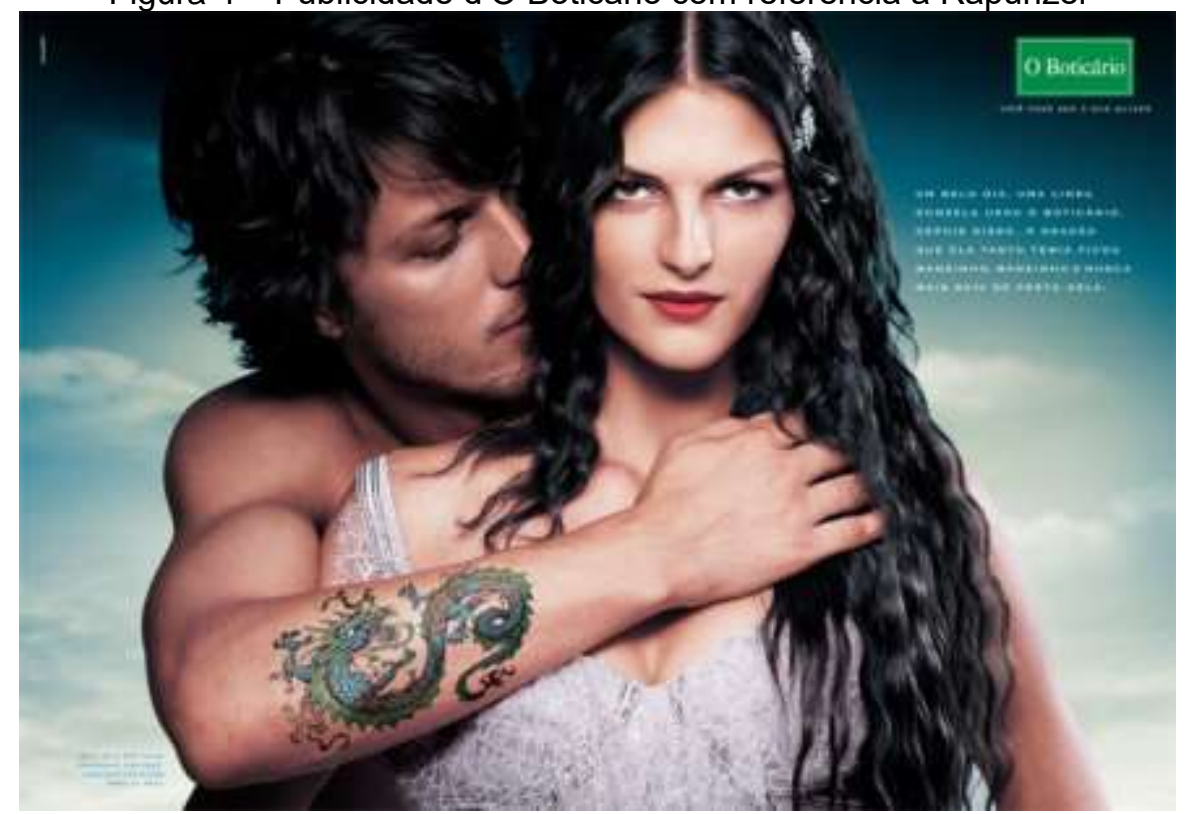

Fonte: http://mundofabuloso.blogspot.com/2008/01/o-boticario-e-suas-princesas.html. Acesso em: 05 fev. 2018.

Nossa última publicidade a ser analisada retoma intertextualmente o conto de fadas Rapunzel. No conto, o estereótipo marcante da princesa é ter lindos e longos cabelos; no ano, entretanto, o que está em primeiro plano é a cena do abraço e o olhar forte e direto da personagem feminina. Aqui, temos uma mistura de delicadeza e sensualidade, pois, na imagem, a "Rapunzel" usa um vestido que traz traços sensuais e, ao mesmo tempo, delicados.

Excepcionalmente, nessa imagem temos a figura masculina, o príncipe que está abraçando a "princesa", fazendo intertexto aos outros contos em que eles saem em busca de suas princesas, e elas, por sua vez, aguardam-nos para desposá-las. Por meio da imagem, identificamos algumas características interdiscursivas de um príncipe, como o cavalheirismo e o romantismo, percebidos pelo olhar e pelo gesto do príncipe ao abraçar a princesa no anúncio publicitário; mas distinguimos, também, traços de um homem da atualidade, no dorso nu, nos traços musculosos do corpo, bem como na tatuagem de dragão no antebraço, o bronzeado do corpo e o corte de cabelo despojado e barba por fazer, o que aumenta o encantamento e a beleza desse novo homem conhecido como metrossexual.

A tatuagem de dragão no braço do jovem pode representar o dragão que amedrontou tantas princesas e também marca a produção de sentidos do 
enunciado verbal: "Um belo dia, uma linda donzela usou O Boticário. Depois disso, o dragão que ela tanto temia ficou mansinho, mansinho e nunca mais saiu de perto dela". Esse enunciado comprova o poder de domínio da mulher que consume os produtos de "O Boticário" e reprime sua insegurança, além de ambicionar homens fortes e belos continuamente próximos e bem "mansinhos", isto é, satisfazendo todas suas vontades.

Nos anúncios em questão, temos sempre imagens de lindas mulheres, todas bem maquiadas e penteadas, trazendo um olhar forte, e, ao mesmo tempo, tenuamente enigmático, fato que nos faz refletir novamente acerca da influência dos cosméticos de "O Boticário" no processo de transformação e poder da mulher, bem como o discurso capitalista. Uma vez que o principal objetivo da marca anunciante é vender seus produtos, utiliza a persuasão sugerindo que todas as mulheres que usam produtos "O Boticário" sejam exatamente aquilo que desejam, como sugere o slogan embaixo do logotipo: "Você pode ser o que quiser". Com os produtos da marca, as mulheres ficarão lindas e fortes como as princesas dos contos de fadas, atualizadas nas publicidades analisadas. 0 interdiscurso presente nesses resgates dos contos de fadas, na medida em que trabalha com a ressignificação da história sobre o que já foi dito em suas versões "originais", determina os deslocamentos promovidos pelo sujeito-consumidor, estabelecendo assim, uma nova formação discursiva, um mundo marcado pelo consumismo e pela idealização pela beleza.

\section{Considerações finais}

Este trabalho almejou demonstrar e mapear alguns aspectos das relações dialógicas que se dão entre as quatro peças publicitárias analisadas e os respectivos contos de fadas em que são inspiradas. Podemos ressaltar a grande importância das reflexões de Bakhtin e Volochínov (2006) no entendimento de como as relações dialógicas se dão em materialidades discursivas distintas: tal como qualquer texto, são sempre estabelecidas dialogicamente a partir de ecos de outros textos. Nesse sentido, compete ao leitor observar e recuperar essas vozes discursivas por meio do acionamento dos seus conhecimentos prévios e da sua memória textual e discursiva. 
As contribuições de Bakhtin (1998) e de Bakhtin e Volochínov (2006) apontam a importância de que o texto seja pensado como enunciado concretamente estabelecido nas situações de interação social. Isso abre espaço para analisarmos tanto o texto constituído pelo signo linguístico como aquele que se constrói com outras materialidades significativas como a imagem, no caso dos textos aqui trabalhados. Entendemos que a teoria bakhtiniana propicia a compreensão do funcionamento discursivo dos textos, pois permite 0 mapeamento de aspectos intertextuais e discursivos que são operacionalizados na produção das publicidades analisas e em sua leitura. Aqui, mais uma vez, é preciso ressaltar que concebemos a leitura como uma prática social por meio da qual os sentidos são produzidos.

A noção de leitura como prática social amplia nosso olhar sobre os textos que circulam socialmente, capacitando-nos para operar o processo de (re)construção dos sentidos possíveis de um determinado texto, situando-o no contexto social, histórico e cultural de que emerge e no qual circula. Nesse sentido, por meio das análises propostas, identificamos relações de intertextualidade e de interdiscurso entre as publicidades selecionadas e os contos de fadas. Essas relações demonstram a maneira como a figura feminina é colocada nas publicidades escolhidas em comparação com o lugar que ocupa nos contos infantis. A releitura feita pelas publicidades destaca a modificação no comportamento, no estilo de vida dessa mulher que está ali retratada, bem como na visão que dela se tem. Essa mulher almeja cada vez mais seu espaço, o que se associa ao estereótipo da mulher contemporânea, mas ainda se submete a modelos e padrões que são reforçados pelas publicidades analisadas.

Em outras palavras, nossa análise permite afirmar que as publicidades analisadas, ao mesmo tempo em que apresentam uma mulher que se liberta do estereótipo das "princesas" dos contos de fadas, configura uma mulher que se submete a determinados padrões de beleza e feminilidade que são próprios da sociedade atual. Entendemos que isso acontece, pois o interesse primeiro dessas publicidades é garantir uma identificação entre possíveis compradoras e a marca "O Boticário", cuja missão é resumida no slogan "Você pode ser o que quiser". Dialeticamente, esse "o que quiser" é delimitado pelo campo de atuação social da empresa anunciante, cujos produtos podem garantir às compradoras, 
à mulher, a chegada ao momento tão esperado do "felizes para sempre", válido tanto para os contos de fada quanto para a vida real.

\section{Referências}

BAKHTIN, Mikhail. Questões de literatura e de estética: a teoria do romance. 4. ed. São Paulo: UNESP/Hucitec, 1998.

BAKHTIN, Mikhail; VOLOCHINOV, Valentin N. Marxismo e filosofia da linguagem. Tradução: Michel Lahud e Yara Frateschi Vieira. 12. ed. São Paulo: Hucitec, 2006.

BRAIT, Beth. Perspectiva dialógica. In: BRAIT, Beth; SOUZA-E-SILVA, Maria Cecília. Texto ou discurso? São Paulo: Contexto, 2012. p. 9-29.

BRASIL, Cláudio. O Boticário e suas princesas. Fantásticas e empoeiradas. Disponível em: http://mundofabuloso.blogspot.com/2008/01/o-boticario-e-suasprincesas.html. Acesso em: 10 maio 2017.

FERNANDES, Cleudemar Alves. Análise do discurso: reflexões introdutórias. Goiânia, GO: Ed. Trilhas urbanas, 2005. (Coleção sala de aula).

FIORIN, José Luiz. Interdiscursividade e intertextualidade. In: BRAIT, Beth. (org.). Bakhtin outros conceitos-chave. São Paulo: Contexto, 2012. p. 160-193.

KNOLL, Graziela Frainer; PIRES, Vera Lúcia. Intertextualidade e propaganda: análise de processos intertextuais em anúncios impressos. In: SEMINÁRIO INTERNACIONAL DE TEXTO, ENUNCIAÇÃO E DISCURSO - SITED, 2010, Porto Alegre. Anais.... Porto Alegre: Núcleo de Estudos do Discurso da Pontifícia Universidade Católica do Rio Grande do Sul, setembro de 2010, p. 210-216.

ORLANDI, Eni P. A análise de discurso e seus entremeios: notas sobre a sua história no Brasil. Cadernos de Estudos Linguísticos, Campinas, n. 42, p. 21 40, jan./jun. 2002.

RESINA, Maria Madalena. A manipulação dos contos de fadas. Miscelânea, Assis, v. 6, p. 156-167, jul./nov. 2009.

SCHOLTZ, Adriana de Jesus; KRUK, Samuel. Os contos fantásticos na publicidade de "O Boticário". In: CONGRESSO DE CIÊNCIAS DA COMUNICAÇÃO NA REGIÃO SUL - INTERCOM SUL, 13., 2012, Chapecó, SC. Anais... Chapecó: Sociedade Brasileira de Estudos Interdisciplinares da Comunicação, 2012, p. 01-12.

SOUZA, Andressa Simões de. Análise discursiva de publicidades para metrossexuais. 2008. 109 f. Dissertação (Mestrado em Linguística) Universidade Federal de Minas Gerais, Faculdade de Letras. Belo Horizonte, 2008. 